INTERNATIONAL JOURNAL OF RESEARCHES IN BIOSCIENCES, AGRICULTURE AND TECHNOLOGY (c) VISHWASHANTI MULTIPURPOSE SOCIETY (Global Peace Multipurpose Socie ty) R. No. MH-659/13 (N) www.vmsindia.org

\title{
PHYTOCHEMICAL AND NUTRITIONAL ANALYSIS OF CARALLUMA FIMBRIATA L.
}

\author{
A D Padwal' ${ }^{1}$ S N Varpe ${ }^{2}$, M B Waman ${ }^{3}$ \\ ${ }_{1}$ S.N. Arts, D.J.M.Comme rce, B.N.S. Science College, Sangamner, Tal: Sangamner, Dist: Ahmednagar, \\ ${ }^{2}$ Nutan Arts, Commerce \& Science College, Rajapur, Sangamner, Tal: Sangamner, Dist: Ahmednagar, \\ ${ }^{3}$ SMBST College, Sangamner, Tal: Sangamner, Dist: Ahmednagar \\ padawalanoopbotany@gmail.com
}

\begin{abstract}
:
In nature, there are many underutilized plants of promising nutritive value, which can nourish the ever increasing human population. They haveremained underutilized due to the lack of awareness and popularization of te chnology. People's diet offers a greater and more diverse group of plant bioactive than do drugs and they often do not realize that many drugs are derived from the compounds which are originally discovered in plants. Plants play an important part in maintaining general good health owing to the presence of nutritional and phytoche mical property. All these substances help to protect the body process, on which vitality and good health depend. They also contain a variety of bioactive non-nutritive health promoting factors. Most of the plants serve as food but the ir nutritional and phytochemical potential has not been overlooked. The present study was to analyze the preliminary phytochemical and nutritional analysis of Caralluma fimbriata L. It is an ethnomedicinal and nutritional plant used for different ailments in the tribal regions of Sangamner tehsil of Ahmednagar district (MS) India. This study reveals the presence of Steroid, Caumarin, Protein, Carbohydrates, Diterpenes, Phytoste rol, Flavonoids, Saponins and alkaloids. The nutritional analysis shows the rich amount of mine ral and ele mental substances. Present study gives an alternative source for pharmaceutical and nutraceuticals industries.
\end{abstract}

Keywords: Phytochemical, Nutritional, Caralluma fimbriata, Pharmaceutical, Nutrace uticals.

\section{Introduction:}

Caralluma fimbriata, also known as Caralluma adscendens, belongs to the family asclepiadacea. In Western India it is also called Ranshabar, Makad shenguli, Kullimudayan, and Shindula makadi. There are other species of Caralluma that grow in India. Among these are: C. indica, C. attenuata, C. umbellata, and C. All the se varieties of Caralluma are botanically and phytochemically similar to C. fimbriata and regularly consumed by the native population across India. Caralluma fimbriata is consumed daily as a vegetable in the Kolli Hills of South India; it is used in pickles and chutney in the arid regions of Andhra Pradesh; and in Western India, Caralluma fimbriata is accepted as a famine food - suppressing appetite and quenching thirst. Legend has it those hunting tribes' chewed chunks of the Caralluma cactus to suppress hunger and thirst when on a long hunt. There are no adverse events reported in the Indian subcontinent over the centuries of use of Caralluma fimbriata. It is listed as a vegetable in The Wealth of India and in Indian Health Ministry's comprehensive compilation on medicinal plants. Key phytochemical ingredients include sitos te rol, Hexadecanoic acid, Ole ic acid, pregnane glycosides, flavone glycosides, megastigman glycosides, bitter principles, alkaloids, saponins, various flavonoids etc. Caralluma has become an extre mely use ful type of "portable food" It is even called as "famine food", since it helps fight off hunger in times of desperate need of food for those who had to travel long distances on land [1].

In nature, the re are many underutilized plants of promising nutritive value, which can nourish the ever increasing human population. They have remained underutilized due to the lack of awareness and popularization of technology [2] [3] [4]. People's diet offers a greater and more diverse group of plant bioactive than do drugs and they often do not realize that many drugs are derived from the compounds which are originally discovered in plants. Plants play an important part in maintaining general good health owing to the presence of nutritional and phytochemical property [5] [6] [7] [8]. All these substances help to protect the body process, on which vitality and good health depend. Most of the plants serve as food but their nutritional and phytochemical potential has not been overlooked [9] [10]. The present study was to analyze the preliminary phytochemical and nutritional analysis of Caralluma fimbriata L. It is an ethnomedicinal and nutritional plant used for different ailments in the tribal regions of Sangamner tehsil of Ahmednagar district (MS) India.

\section{Materials and Methods:}

\section{Collection and Identification:}

Plant sample was collected from the forest areas of Sangamner tehsil. Identification 
was done with the help of Flora of Ahmednagar Dis trict [1 1 ].

\section{Phytochemical screening:}

The powder is used for the phytochemical analysis both qualitative as well as quantita tive phytochemical screening for the identification of the various classes of active chemical constituents, using standard prescribed methods [12]. The positive tests were noted as weak $(+)$, moderate $(++)$, strong $(+++)$ and absent $(-)$.

Plant filtrate was prepared by boiling $20 \mathrm{~g}$ of the powder of the plant in distilled water. The solution was filtered. The filtrate was used for the phytochemical screening of flavonoids, tannins, saponins, alkaloids, reducing sugars, anlhraquinones and anthocyanosides.

\section{Alkaloids}

$1 \mathrm{ml}$ of the bark filtrate was mixed with $2 \mathrm{ml}$ of Dragendoff $\mathrm{s}$ reagent; a turbid orange colour indicated the presence of alkaloids. The confirmation test was done using Mayer's reagent; a yellow precipitate indicated the pre sence of the alkaloids.

\section{Tannins}

$1 \mathrm{ml}$ of the filtrate was mixed with $2 \mathrm{ml}$ of $\mathrm{FeCl}_{2}$; a dark green colour indicated a positive test for the tannins.

\section{Saponins}

$1 \mathrm{ml}$ of the plant filtrate was diluted with $2 \mathrm{ml}$ of distilled water, the mixture was vigorously shaken and left to stand for $10 \mathrm{~min}$ during which time, the development of foam on the surface of the mixture lasting for more than 10 min, indicates the presence of saponins.

\section{Anth ocy anosides}

$1 \mathrm{ml}$ of the bark filtrate was mixed with $5 \mathrm{ml}$ of dilute $\mathrm{HC} 1$; a pale pink colour indicates the positive test.

\section{Flavonoids}

$1 \mathrm{ml}$ of bark filtrate was mixed with $2 \mathrm{ml}$ of $10 \%$ lead acetate; a brownish precipitate indicated a positive test for the phenolic flavonoids. While for flavonoids, $1 \mathrm{ml}$ of the plant filtrate was mixed with $2 \mathrm{ml}$ of dilute $\mathrm{NaOH}$; a golden yellow colour indicated the presence of flavonoids.

\section{Steroid}

Liebermann-Burchard reaction was performed for the presence of steroids. A chloroformic solution of the crude powder was treated with ace tic anhydride and few drops of concentrated H2SO4 we re added down the sides of test tube. A blue green ring indicated the presence of steroids.

\section{Amino acids}

Small quantities of extract were dissolved in a few $\mathrm{ml}$ of water and treated with Ninhydrin reagent. A purple colouration obtained showed the presence of a mino acids.

\section{Proteins}

Small quantities of extract we re dissolved in a few $\mathrm{ml}$ of water and treated with Biuret reagent. A violet colouration obtained showed the presence of proteins.

\section{Carbohydrates}

A small quantity of powder were dissolved separately in $5 \mathrm{ml}$ of distilled water and filtered. The filtrate was subjected to Molisch's test to de tect the presence of carbohydrates.

\section{Cardiac glycosides test}

Keller-kiliani test was performed for the presence of cardiac glycosides. The crude powder each was treated with $1 \mathrm{ml}$ mixture of $5 \% \mathrm{FeCl} 3$ and glacial acetic acid (1:99 v/v). To this solution, few drops of concentrated H2SO4 were added. Appearance of greenish blue color with in few minutes indicated the presence of cardiac glycosides.

\section{Phenol test}

The powder was treated with few drops of diluted sodium hydroxide $(\mathrm{NaOH})$ separately. Formation of intense yellow color which turned colorless on addition of few drops of diluted $\mathrm{HCl}$ indicated pre sence of phe nol.

\section{Phlobatanins test}

The crude powder was boiled with $1 \%$ aqueous $\mathrm{HCl}$. Deposition of red precipitate was taken as evidence for the presence of phlobatanins.

\section{Nutritional Analysis}

Mineral and elemental analysis of powder was done by using standard methods (13).

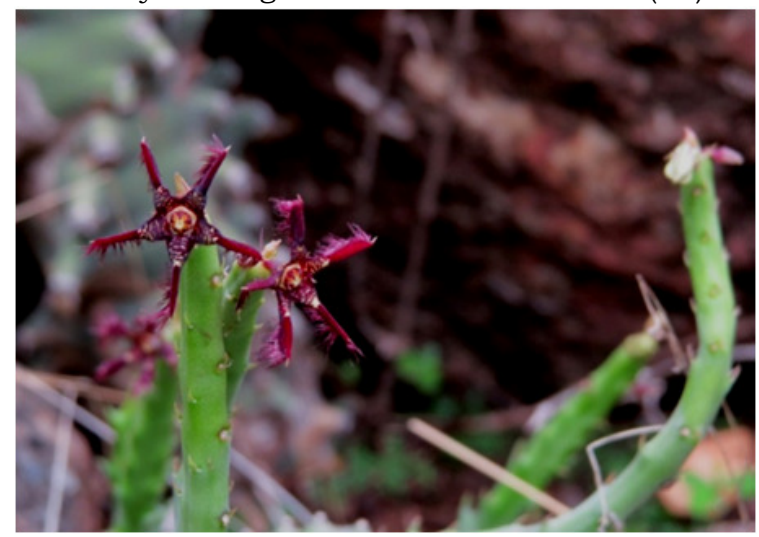

Caralluma fimbriataL. 
Table 1. Pre liminary Phy to chemical screening.

\begin{tabular}{|l|l|l||}
\hline $\begin{array}{l}\text { Sr. } \\
\text { No. }\end{array}$ & Phytochemical constituents & Inference \\
\hline \hline 1. & Steroid & +++ \\
\hline \hline 2. & Anthocyanin & - \\
\hline 3. & Caumarin & +++ \\
\hline \hline 4. & Protein & +++ \\
\hline 5. & Amino acid & - \\
\hline 6. & Carbohydrate s & +++ \\
\hline 7. & Diterpenes & ++ \\
\hline 8. & Phytosterol & +++ \\
\hline \hline 9. & Phenol & - \\
\hline \hline 10. & Flavonoids & +++ \\
\hline \hline 11. & Tannins & - \\
\hline \hline 12. & Phobatannin & - \\
\hline 13. & Cardinal glycoside & - \\
\hline \hline 14. & Saponins, & ++ \\
\hline \hline 15. & Alkaloids & +++ \\
\hline
\end{tabular}

Note: + Low, ++ Moderate, +++ High, --- Absent.

Table 2. Mineral and elemental constituents

\begin{tabular}{|l||l||l||}
\hline \hline Sr. No. & $\begin{array}{l}\text { Mineral and elemental } \\
\text { constituents }\end{array}$ & Inference \\
\hline \hline 1. & Ash value & $5.96 \%$ \\
\hline \hline 2. & Fats & $8.13 \%$ \\
\hline 3. & Total sugar & $31.58 \%$ \\
\hline \hline 4. & Crude fiber & $6.18 \%$ \\
\hline \hline 5. & Dry mater & $76.28 \%$ \\
\hline \hline 6. & Iron as Fe & $0.0006 \%$ \\
\hline \hline 7. & Zinc & $0.003 \%$ \\
\hline 8. & Copper & $0.00064 \%$ \\
\hline \hline 9. & Nitrogen & $3.54 \%$ \\
\hline \hline 10. & Potassium & $1.34 \%$ \\
\hline \hline 11. & Phosphorous & $1.04 \%$ \\
\hline \hline 12. & Sodium & $0.0026 \%$ \\
\hline 13. & Calcium & $0.12 \%$ \\
\hline \hline 14. & Magnesium & $0.006 \%$ \\
\hline \hline 15. & Silica & $4.92 \mathrm{ppm}$ \\
\hline \hline 16. & Calorie value & $\begin{array}{l}5548.64 \\
\text { Kcal/ Kg }\end{array}$ \\
\hline \hline
\end{tabular}

\section{Result and Discussion:}

The medicinal value of plants lies in some che mical active substances that produce a de finite physiological action on the human body. This study reveals the presence of Steroid, Caumarin, Protein, Carbohydrates, Diterpenes, Phytosterol, Flavonoids, Saponinsand alkaloids.There are records that show the benefits of these compounds detected from Caralluma fimbriata $L$. The nutritional analysis shows the adequate amount of nutritional compounds which are required to fulfill the daily need of diet.

\section{Conclusion:}

Present study gives the detail study of phytochemical and nutritional features so it should be an alte rnative source of food and also be cultivate on large scale.

\section{References:}

1. Priya D, Rajaram K, Suresh Kumar. Intl J Pharm Res Develop; 3(10):105-110 (2011).

2. Sheela. Proximate Composition of Underutilized Green Leafy Vegetables in Southern Karnataka. J Hum Ecol.; 15(3):22 7-229. (2004)

3. FAO. Fruit and Vege table for health. Report of a joint FAO/WHO workshop. 2005.

4. Anon P, Opabode JI and Adegboye OC. Application of biotechnology for the improvement of nigerian indige nous leafy vege tables. Africa J Biote ch.;4(3): 138-142. (2005)

5. Gupta S, Lakshmi JA and Prakash J. Effect of different blanching treatment on ascorbic acid retention in green leafy vegetables. Natural product radiance.;7(2):111-116. (2008)

6. Borget, M. Spices plants. In: R. Coste (ed.), The tropical Agriculturist, Macmillan, London,, p 114. (1993)

7. Shelef, L.A. Antimicrobial effects of spices. J. Food Safety. 6: 29-44, (1983).

8. Zaika, L.L. Spices and herbs: Their antimicrobial activity and its determination. J. Food Safety. 9: 97-118, (1988)

9. Sofowora A. Medicinal plants and Traditional Medicine in Africa. Ibadan:Spectrum Books; p. 150.(1993)

10. Okwu D.E. Evaluation of the chemical composition of indigenous Spices and flavoring Agents. Global J. Pure Appl. Sci. 7(3): 455-459,(2001)

11. Pradhan, S.G., Singh, N.P. Flora of Ahmednagar District (M.S) Bishen Singh Mahendra Pal Singh, Dehradun. India(1999).

12. Harbone, J.B. Phytochemical Methods, Chapman and Hall, Ltd., London, p4'\}.188(1973).

13. AOACOfficinal Methods of Analysis,' Association of Official analytical Chemicals, 15 th edition, Arling ton U.S.A (1990). 